\section{Praktisk om prosedyrer}

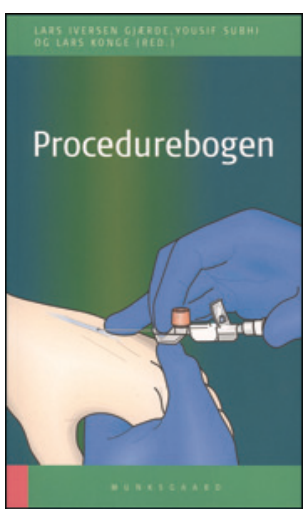

Lars Iversen Gjærde, Yousif Subhi,

Lars Konge, red.

Procedurebogen

135 s, ill. København: Munksgaard, 2014.

Pris DKK 275

ISBN 978-87-628-1238-3

Denne lille boken i frakkelommeformat er en praktisk veileder der 51 kliniske prosedyrer blir gjennomgått. Målgruppen er først og fremst nyutdannede leger og medisinstudenter, men den kan være nyttig også for sykepleiere og annet helsepersonell. Forfatterne er en stor gruppe danske leger med lang erfaring i undervisning i praktiske ferdigheter, og innholdet er kvalitetssikret ved hjelp av erfarne spesialister innen hvert fagfelt.

Det er ikke tatt med verken teoretisk bakgrunn, indikasjoner eller kontraindikasjoner til noen av prosedyrene, noe redaktørene understreker i forordet. Hensikten med utgivelsen er å veilede detaljert i praktisk utførelse av vanlige prosedyrer som de fleste leger har nytte av å kunne. Prosedyrene blir gått gjennom trinn for trinn ved hjelp av enkle illustrasjoner og kort, konsis tekst. For hver prosedyre er det fire tekstbokser, én om forberedelser, én om informasjon som bør gis til pasienten, én med utstyrsliste og avslutningsvis én tekstboks om problemløsning.

Det meste er tatt med, fra arteriepunksjon, EKG-undersøkelse og reponering av skulderluksasjon til syning av lik. Hjerte-lungeredning vies seks sider, mens de fleste andre prosedyrene får fra to til fire sider.

Boken er et godt supplement for å føle større trygghet i utførelsen av praktiske prosedyrer som man ikke har gjort så mange ganger, eller som det har gått en stund siden man fikk demonstrert. Som turnuslege har jeg hatt nytte av flere av prosedyregjennomgangene i boken, og den kan anbefales til alle som ønsker å bli tryggere og bedre på korrekt utførelse av vanlige kliniske prosedyrer!

Matilde Risopatron Berg

Turnuslege, Sykehuset Innlandet, Hamar

\section{En god lærebok i blodsykdommer}

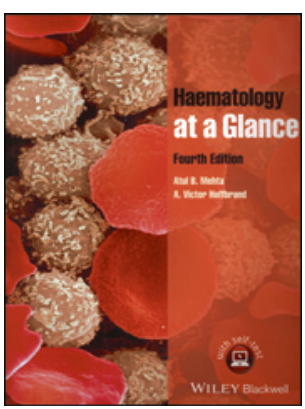

Atul B. Mehta, A. Victor Hoffbrand Haematology at a glance

4. utg. 135 s, tab, ill. Chichester: Wiley-Blackwell, 2014. Pris GBP 27 ISBN 978-1-119-96922-8

Haematology at a glance er en av bøkene i «at a Glance»-serien. Den er primært rettet mot medisinstudenter, leger under spesialisering og annet helsepersonell som ønsker seg en rask oversikt over temaet blod og blodsykdommer.

Denne nye utgaven er delt opp i åtte deler, der hovedparten omtaler normal fysiologi, sykdommer i røde blodceller, benigne blodsykdommer, maligne blodsykdommer og sykdommer relatert til hemostase. I tillegg omtales blodsykdommer hos barn, hematologiske aspekter ved svangerskap, ved blodtransfusjon og ved tropiske sykdommer som malaria og leishmaniasis. Boken gir en god oversikt over blodets normale fysiologi og over blodsykdommer, samt de siste oppdateringer innen feltet. Alle viktige temaer innenfor blodsykdommer, inkludert lymfomer, er beskrevet. Autolog og allogen stamcelletransplantasjon er også omtalt. Boken er kompakt og konsist skrevet. Dessverre er mye viktig kunnskap og de nyeste, aksepterte behandlingene ofte nevnt bare med en setning eller to.

Illustrasjonene er gode. Bilder av pasienter, blod og beinmargsutstryk virker derimot ikke alltid helt overbevisende, spesielt ikke for dem som ikke jobber med blodsykdommer i det daglige. Som forfatterne sier i forordet, bør boken ikke brukes til å stille diagnose eller starte behandling av blodsykdommer uten veiledning fra spesialist i blodsykdommer. Derimot kan den anbefales til medisinstudenter som trenger en gjennomgang i forkant av forelesningene eller en repetisjon før eksamen. Den tilhørende nettsiden med flervalgsoppgaver og presentasjon av kliniske tilfeller er relevant og pedagogisk. For leger under spesialisering, spesielt de som jobber $i$ en indremedisinsk avdeling, kan boken være en god kilde til repetisjon og oppdatering innen blodsykdommer.

\section{Hoa Thi Tuyet Tran}

Overlege, Avdeling for blodsykdommer Akershus universitetssykehus 